Buana Sains Vol 17 No 2: 125 - 136, 2017

\title{
EVALUASI KESESUAIAN LAHAN TANAMAN JAGUNG, KUBIS, KENTANG DAN WORTEL DENGAN MENGGUNAKAN PROGRAM ALES (Autometed Land Evaluation System)
}

\author{
Bambang Siswanto dan Wahyu Fikrinda \\ Program Studi Agroteknologi, Fakultas Pertanian, Universitas Tribhuwana Tunggadewi
}

\begin{abstract}
The increasing need of land from year to year results in the narrowness of fertile and potential agricultural land. This condition causes an imbalance of land use, which can directly harm the agricultural sector. To be able to utilize land resources in a directed and efficient manner, it is necessary to provide complete data and information about land characteristics and land use requirements that will be cultivated. Information in the form of land characteristics and land use requirements is needed in land evaluation activities. Land evaluation conducted by using ALES program (autometed land evaluation system), in addition to facilitate the process can also be used for the evaluation of land economically. To evaluation land physical and economical for maize, cabbage, potato and carrot in Tulungrejo, Batu.

This research was conducted in Tulungrejo Substrict region in Tulungrejo, Batu observation map plan soil and economic social data processing, evaluation model on ALES program. The research result was 17 soil mapping unit (SMU) according to soil survei result which consist of soil taxonomi with its spread SMU 1 Andic Dytrudepts, SMU 2 Andic Dystrudepts and Typic Melanudands, SMU 3 Andic Dystrudepts and Typic Melanudans, SMU 4 Typic Melanudands, SMU 5 Andic Dystrudepts and Typic Melanudands, SMU 6 Humic Pachic Dystrudepts, SMU 7 Ruptic Alfic Dystrudepts, SMU 8 Andic Dystrudepts, Tupic Dystrudepts and Typic Melanudands, SMU 9 Typic Hapludans, SMU 10 Typic Melanudands, SMU 11 Typic Hapludands and Andic Hapludolls, SMU 12 Typic Hapludands and Humic Dystrudepts, SMU 13 Typic Hapludands and Inceptic Hapludalfs, SMU 14 Typic Hapludolls, SMU 14 Typic Hapludolls, SMU 15 Typic Hydrudands, SMU 16 Typic Melanudands and Andic Dystrudepts, SMU 17 Typic Udipsamments. Generally the ALES physical land suitability result for maize: S3-eh/nf/nr/rc, S2-nr/rc/wa, S3-oa and N-oa, cabbage S3eh, S3-eh/nr, S3-nf, S3-rc and N-oa, potato S2-eh/nr, S2-nf, S3-nr, S3-oa and N-oa while for carrot S3-nf, N-eh. Economical land suitability value of maize, cabbage and potato on N1, N2 and S3 while for carrot is S1 because nothing limited class. General the ALES economical suitability result was profitable because there ware no negative (-) economical matric value.
\end{abstract}

Keywords: Land, evaluation, ALES program 


\section{Pendahuluan}

Kebutuhan lahan untuk keperluan pengunaan lahan diluar pertanian yang semakin meningkat dari tahun ke tahun berakibat terhadap semakin sempitnya lahan-lahan pertanian yang subur dan potensial. Kondisi yang demikian ini menyebabkan adanya ketidakseimbangan penggunaan lahan, yang secara langsung dapat merugikan sektor pertanian. Untuk dapat memanfaatkan sumber daya lahan secara terarah dan efisien diperlukan tersedianya data dan informasi yang lengkap mengenai karakteristik lahan dan persyaratan pengunaan lahan yang akan diusahakan.

Informasi berupa karakteristik lahan dan persyaratan penggunaan lahan sangat diperlukan dalam kegiatan evaluasi lahan. Evaluasi lahan yang dilakukan dengan menggunakan program ALES (autometed land evaluation system), selain memudahkan dalam pengerjaannya juga dapat digunakan untuk evaluasi lahan secara ekonomi. Diharapakan dengan melakukan pekerjaan evaluasi lahan, maka akan dapat ditetapkan jenis penggunaan yang lebih produktif sehingga produksi juga meningkat dan lebih menguntungkan, kususnya di Desa
Tulungrejo yang merupakan salah satu daerah sentra penghasil tanaman semusim di Kota batu. Tujuan dari kegiatan evaluasi lahan ini adalah untuk mengetahui kelas kesesuaian lahan tanaman jagung, kubis, kentang dan wortel secara fisik dan ekonomi. Dengan melakukan evaluasi lahan tersebut diharapkan dapat memperbaiki pola budidaya pertanian khususnya untuk tanaman semusim, dengan demikian dapat meminimalisir kesalahan dalam pengelolaannya.

\section{Metode Penelitian}

Penelitian dilakukan di Desa Tulungrejo, Batu . Penelitian dilakukan pada bulan Mei sampai Juni 2013. Penelitian dilakukan dengan mengumpulkan data dan informasi sekunder dari pustaka yang ada, selanjutnya dilakukan survei pendahuluan dan pembuatan peta dasar berupa peta satuan peta lahan (SPL), survei lapang, pengambilan contoh tanah, analisa laboratorium (FAO, 1976 dan Rayes, 1995) dan pengolahan data menggunakan program ALES. Tahapan evaluasi lahan dengan ALES dapat dilihat pada Gambar 1.

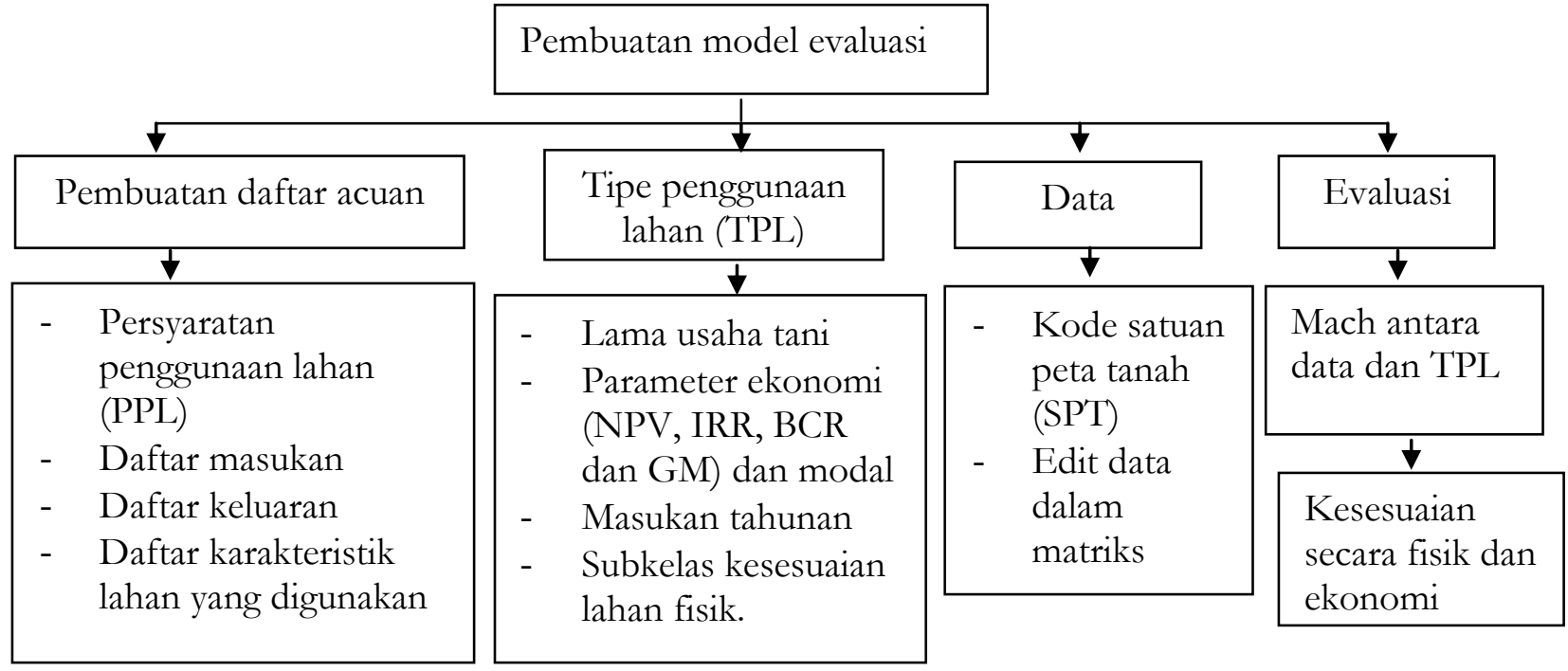

Gambar 1. Alur pekerjaan dengan program ALES 


\section{Kondisi Umum Wilayah}

Desa Tulungejo, Kecamatan Bumiaji, Kota Batu, Malang adalah desa yang berbatasan dengan Desa Sumberbrantas pada sebelah Utara, di sebelah Timur berbatasan dengan Desa Sumbergondo, sebelah Selatan berbatasan dengan Desa Punten dan sebelah Barat berbatasan dengan lahan hutan Kecamatan Pujon Kabupaten Malang. Secara geografis Desa Tulungrejo terletak pada $59341,77821 \mathrm{E}-6348269,02589 \mathrm{~N}$.

Tipe iklim menurut Oldeman termasuk D4, karena terdapat bulan basah berturut-turut 3-4 bulan dengan curah hujan lebih dari $200 \mathrm{~mm} /$ bulan dan bulan kering 7-9 bulan dengan curah hujan kurang dari $100 \mathrm{~mm} /$ bulan. Curah hujan rata-rata tahunan Desa Tulungrejo berkisar $1.346 \mathrm{~mm} /$ th.

Topografi desa Tulungrejo adalah datar sampai berbukit. Terletak pada ketinggian $1.115 \mathrm{~s} / \mathrm{d} 1700 \mathrm{~m}$ dpl, dengan kelerengan $3^{0} \mathrm{~s} / \mathrm{d}>60^{\circ}$. Desa Tulungrejo termasuk di dalam dataran antar vulkanik Gunung Anjasmoro dan Gunung Arjuno. Desa Tulungrejo memiliki tiga formasi geologi, yaitu Qvaw, Qvat dan Qpva. Sedangkan landform yang terdapat pada daearah penelitian antara lain:

1. Al : Lembah-lembah lahar merupakan parit dan jurang erosi yang tua, berasal dari kerucut gunung bagian atas yang curam, yang kemudian dipenuhi oleh bahan-bahan lahan kasar (umumnya lahar dingin atau lahar hujan).

2. Ac : Berupa lembah koluvial yang cekung, tidak terbentuk baik, atau diubah manusia karena sudah diteras untuk diusahakan seperti penanaman jagung, pisang, wortel, dan beberapa ditanami apel.
3. Pu : Dataran tinggi dan plato, merupakan satuan bentuk lahan yang terbesar di Desa Tulungrejo.

4. Ps : Lereng plato yang curam.

5. Pc : Plato yang terdapat bahan koluvial.

6. Hd : Bukit tertoreh dengan punggung tajam sejajar

7. Hp : Bukit plato dan spurs. Satuan ini meliputi : (1) Bukit plato yang kecil dan terisolir, dan terletak pada spurs bukit yang landai dan punggung (crests). (2) Plato yang agak landai (cembung, 3-8) dan spurs bukit yang cekung/cembung, agak curam.

8. Hc : Koluvial kaki bukit dan kaki lereng, landai sampai agak landai.

9. Hs : Lereng-lereng bukit, curam sampai agak terjal.

10. Ms : Lereng-lereng yang curam.

Pada lokasi penelitian ditemukan

lima ordo tanah yaitu, Andisol, Inceptisol, Alfisol Entisol Dan Mollisol. Tanah-tanah tersebut termasuk dalam tanah yang subur, karena masih dapat dimanfaatkan sebagai lahan pertanian, meskipun tingkat produksi yang dihasilkan berbeda. Tingkat produksi bisa berbeda pada jenis ordo yang sama dan pada tingkat subgroup yang berbeda. anah Andisol dipengaruhi oleh aktifitas vulkan dan cocok untuk budidaya pertanian tanaman hortikultura, perkebunan dan hutan (Munir, 1996). Pada daerah penelitian ditemukan tiga subgroup yaitu Typic Hapludands, Typic Hydrudands dan Typic Melanudands. Jenis tanah ini terletak pada kelerengan yang beragam dan dekat dengan daerah yang berbukit karena masih terpengaruh dengan aktifitas volkan.Tanah Inceptisol merupakan tanah yang tergolong masih muda dan mulai berkembang. Profilnya mempunyai horison yang dianggap pembentukanya agak lamban sebagai alterasi bahan induk. Pada daerah penelitian ditemukan empat subgroup 
antara lain Andic Dystrudepts, Humic Dystrudepts, Ruptic Alfic Dystrudepts dan Humic Pachic Dystrudepts.Tanah Alfisols merupakan salah satu tanah yang tergolong subur keberadaan tanah ini, pada lokasi penelitian yang tergolong sedikit jika dibandingkan dengan ordo lainya yang ditemukan. Inceptic Hapludalfs adalah pengkelasan tanah sampai subgroup yang ditemukan pada lokasi penelitian.Tanah Mollisol dicirikan dengan warna tanah yang gelap dan kandungan bahan organik yang tinggi sehingga tanah ini termasuk tanah yang tergolong subur karena proses terjadinya erosi yang lambat sehingga kandungan hara yang terdapat pada tanah tersebut tidak hilang dan cukup tersedia bagi pertumbuhan tanaman. Pada lokasi penelitian terdapat tiga subgroup yang dapat ditemukan yaitu, Andic Hapludolls, Aquic Hapludolls, dan Typic Hapludolls. Dari gambar di atas dapat diketahui bahwa sebagian besar tanah yang ada di Desa Tulungrejo adalah tanah Inceptisols yang terletak pada Dusun Wonorejo, Junggo, Kekep dan Gondang
Pengggunaan lahan di Desa Tulungrejo sebagian besar digunakan untuk lahan pertanian. Pemanfaatan lahan untuk pertanian dari lahan berupa perkebunan sawah dan tegalan. Lahan berupa tegalan merupakan lahan yang paling luas yaitu sekitar 445,89 ha dan dimanfaatkan untuk tanaman semusim seperti jagung, kentang, wortel, kubis, tomat, cabe dan tanaman umbi-umbian. Penggunaan lahan lain selain tegalan antara lain hutan alami, hutan reboisasi, pemukiman, lahan terbuka, semak dan sawah. Pemanfaatan lahan untuk lahan pertanian terutama untuk tanaman semusim dilakukan di sawah, tegalan dan daerah perhutani. Penggunaan lahan untuk pertanian didominasi di daerah utara dengan bentuk lahan berupa dataran tinggi dan perbukitan. Lahan pertanian banyak dilakukan didaearah tersebut, karena lahan tersebut sangat mendukung untuk untuk usaha pertanian, meskipun terdapat beberapa faktor pembatas yang berpengaruh tetapi masih dapat diusahakan untuk perbaikannya

Tabel 1. Luasan Penggunaan Lahan Desa Tulungreo

\begin{tabular}{|c|c|c|c|}
\hline \multirow{2}{*}{ No } & \multirow{2}{*}{ Penggunaan lahan } & \multicolumn{2}{|c|}{ Luas } \\
\hline & & (Ha) & $(\%)$ \\
\hline 1 & Hutan alami & 1,13 & 0,11 \\
\hline 2 & Hutan reboisasi & 9,83 & 1,05 \\
\hline 3 & Pemukiman & 27,26 & 2,92 \\
\hline 4 & Lahan terbuka & 124,92 & 13,41 \\
\hline 5 & Perkebunan & 222,94 & 23,94 \\
\hline 6 & Sawah / sayuran & 44,82 & 4,81 \\
\hline 7 & Semak & 54,15 & 5,81 \\
\hline 8 & Tegalan & 445,89 & 47,89 \\
\hline & Total & 930,99 & 100 \\
\hline
\end{tabular}

Penutupan lahan berupa hutan alami dengan luasan yang paling sedikit jika dibandingkan dengan penggunaan lahan lainnya, yaitu 1.13 ha, ini dikarenakan pertambahan penduduk yang setiap tahun semakin meningkat sehingga mengurangi luasan lahan untuk lahan hutan mengingat sejarah pengggunan lahan Desa Tulungrejo adalah hutan. 
B. Siswanto dan W. Fikrinda/ Buana Sains Vol 17 No 2 : 125-136

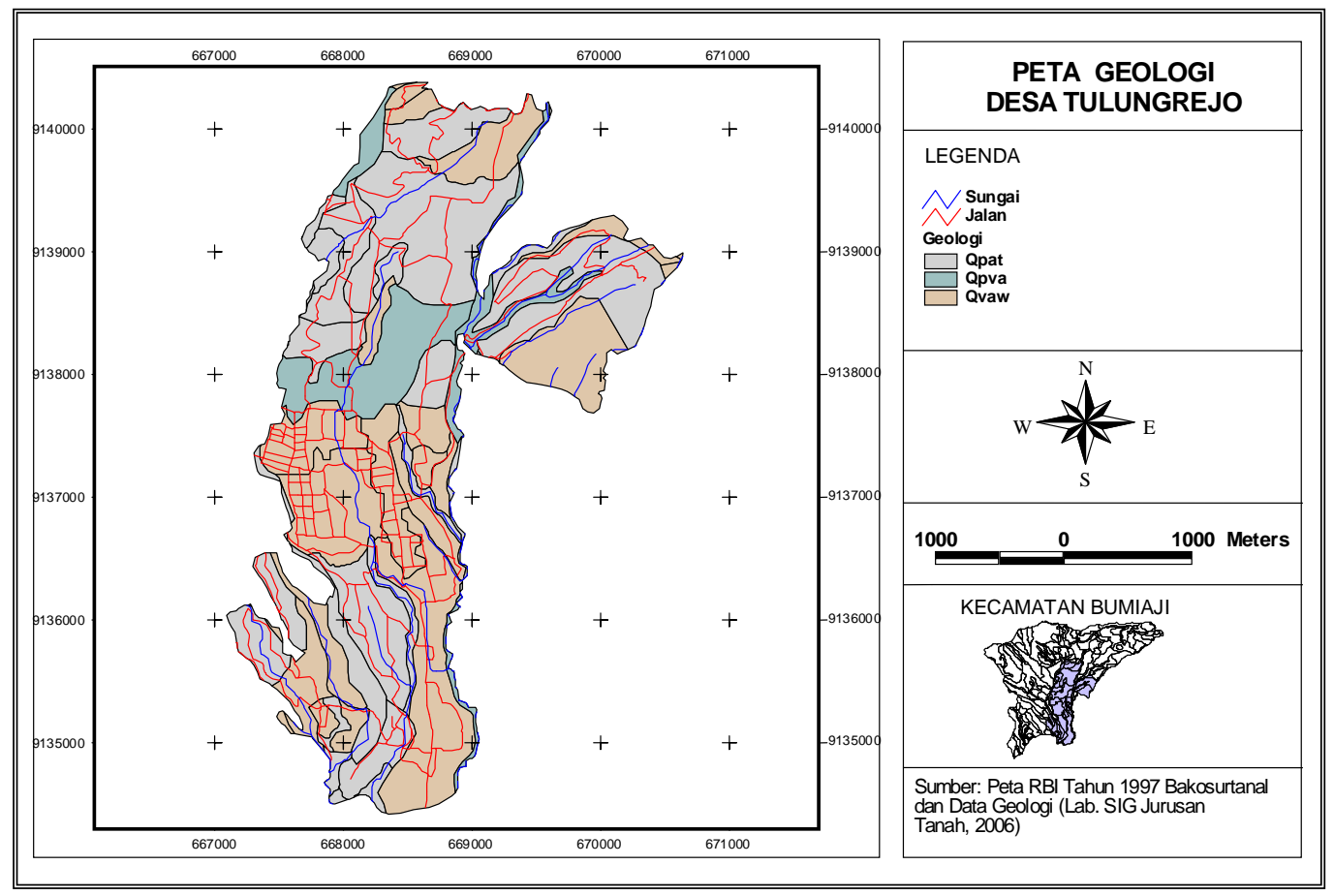

Gambar 2. Peta Geologi Desa Tulungrejo

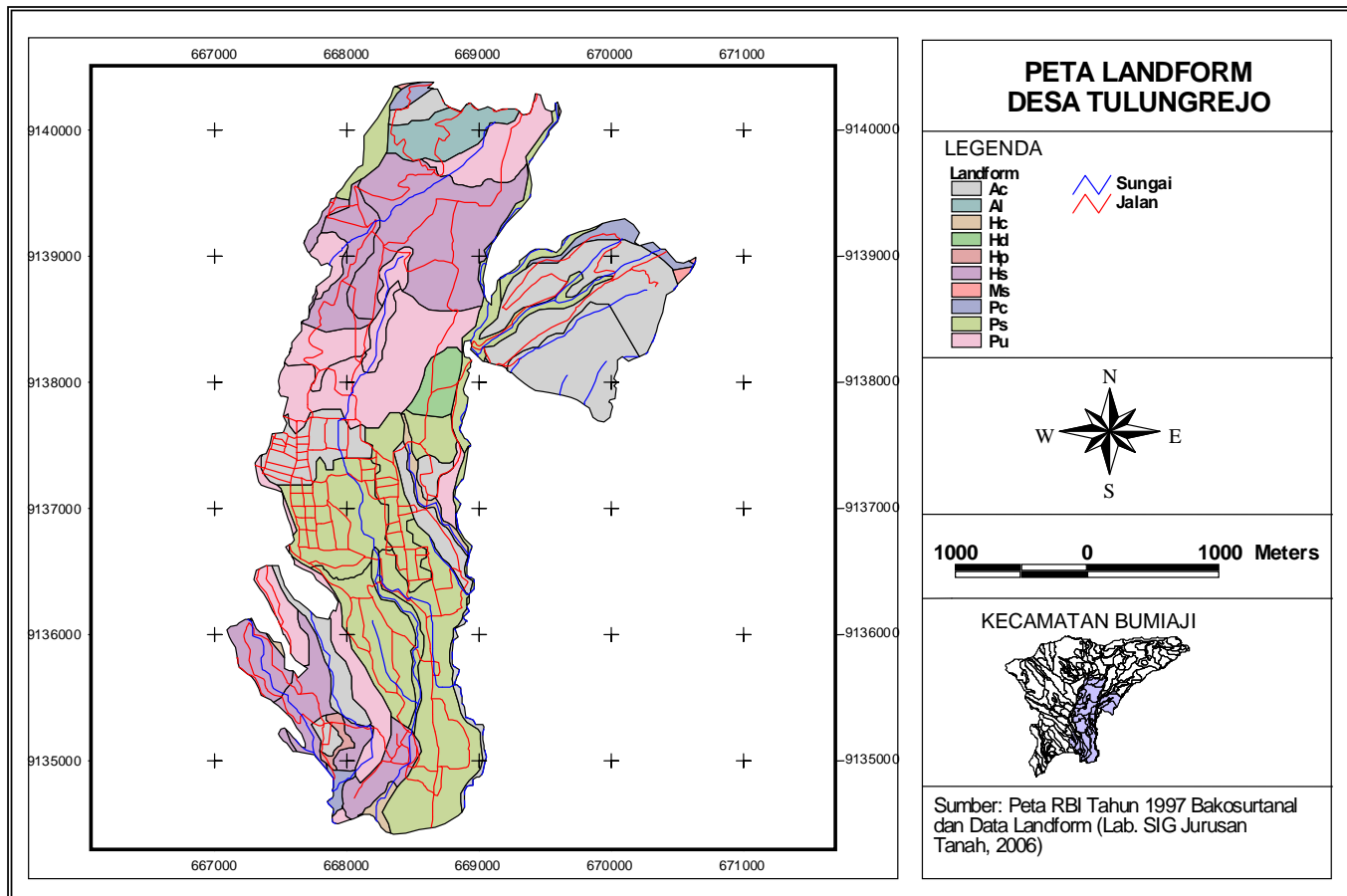

Gambar 3. Peta Landform Desa Tulungrejo 


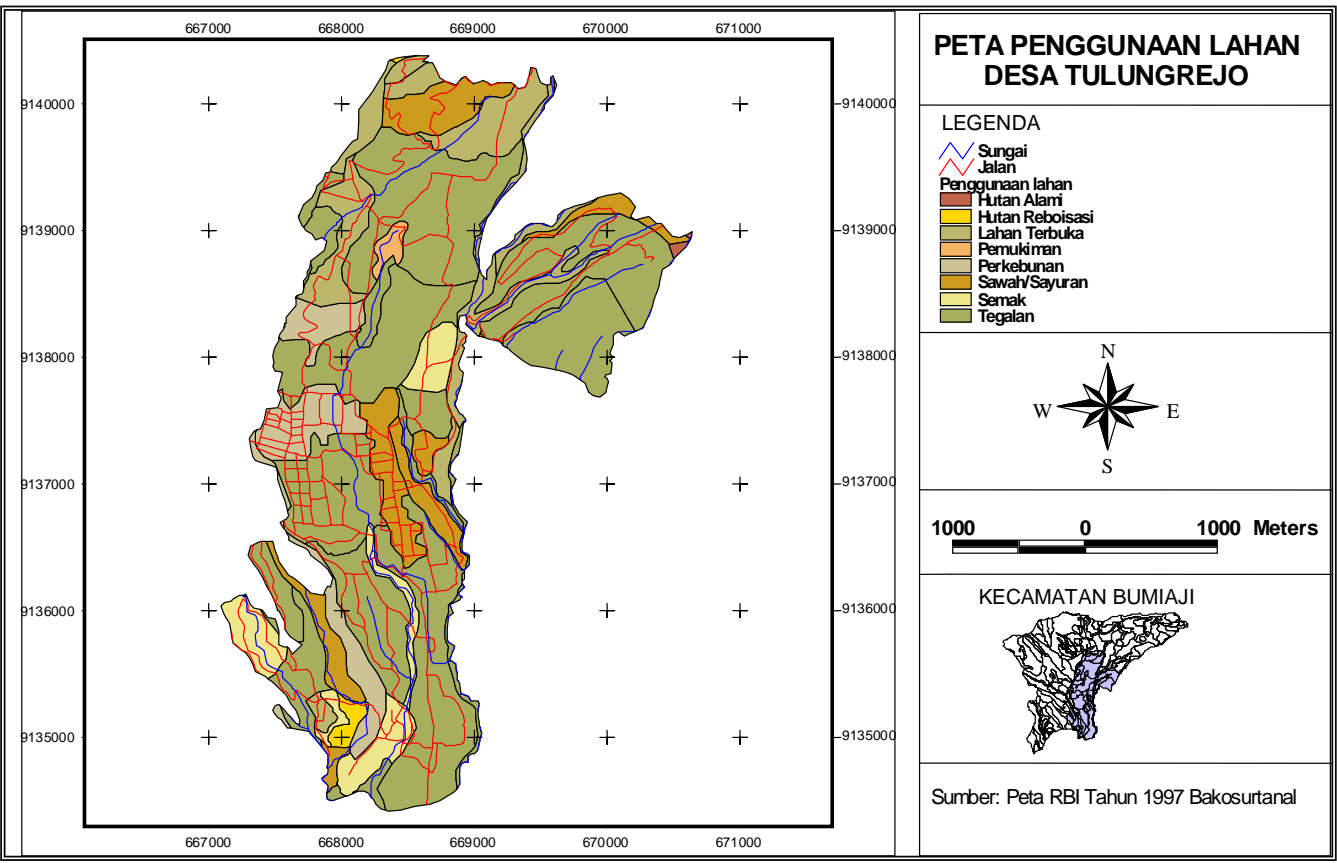

Gambar 4. Peta Penggunaan Lahan Desa Tulungrejo

\section{Hasil dan Pembahasan}

\section{Satuan Peta Tanah}

Berdasarkan kunci taksonomi tanah Soil Survei Staff (1998), terdapat lima ordo tanah, yaitu Entisols, Inceptisols, Andisols, Mollisols dan Alfisols. Pada kategori subgrup terdapat 17 taksa tanah (Tabel 2).

\section{Kualitas dan Karakteristik Lahan}

Kualitas dan karakteristik lahan yang digunakan untuk keperluan evaluasi lahan berdasarkan kriteria yang digunakan Djaenudin (2003) yaitu temperatur, ketersediaan air, media perakaran, retensi hara, bahaya erosi dan ketersediaan hara (Hardjowigeno and Widiatmaka, 2003).

Tabel 2. Kualitas dan karakteristik lahan

\begin{tabular}{|c|c|c|}
\hline No & Kualitas lahan & Karakteristik lahan \\
\hline 1 & Temperatur & - Temperatur rerata \\
\hline 2 & Ketersediaan air & - Curah hujan \\
\hline 3 & Ketersediaan oksigen & - Drainase \\
\hline 4 & Media perakaran & $\begin{array}{l}\text { - Tekstur } \\
\text { - Kedalaman tanah }\end{array}$ \\
\hline 5 & Retensi Hara & $\begin{array}{l}\text { - KTK liat } \\
\text { - Kejenuhan basa } \\
\text { - } \mathrm{pH} \mathrm{H}_{2} \mathrm{O} \\
\text { - } \mathrm{C} \text {-organik } \\
\end{array}$ \\
\hline 6 & Hara tersedia & $\begin{array}{l}\text { - } \mathrm{N} \text { - total } \\
\text { - } \mathrm{P}_{2} \mathrm{O}_{5} \\
\text { - } \mathrm{K}_{2} \mathrm{O} \\
\end{array}$ \\
\hline 7 & Bahaya erosi & $\begin{array}{l}\text { - Lereng } \\
\text { - Bahaya erosi }\end{array}$ \\
\hline
\end{tabular}


B. Siswanto dan W. Fikrinda/ Buana Sains Vol 17 No 2 : 125-136

Tabel 3. Satuan Peta Tanah

\begin{tabular}{|c|c|c|c|c|}
\hline \multirow{2}{*}{ No } & \multirow{2}{*}{ Landform } & \multirow{2}{*}{ Jenis Tanah } & \multicolumn{2}{|c|}{ Luas } \\
\hline & & & $\mathrm{Ha}$ & $\%$ \\
\hline 1 & Lereng plato yang curam & Andic Dystrudepts & 84,38 & 9,06 \\
\hline 2 & Lembah-lembah aliran lahar & $\begin{array}{l}\text { Asosiasi Andic } \\
\text { Dystrudepts } \\
\text { Lithic Udipsamments }\end{array}$ & 24,57 & 2,63 \\
\hline 3 & Lereng plato yang curam & $\begin{array}{l}\text { Asosiasi Andic } \\
\text { Dystrudepts } \\
\text { Typic Hapludands }\end{array}$ & 437,65 & 47,01 \\
\hline 4 & $\begin{array}{l}\text { Lereng bukit, curam sampai agak } \\
\text { terjal }\end{array}$ & Typic Melanudands & 0,06 & 0,01 \\
\hline 5 & $\begin{array}{l}\text { Lereng bukit, curam sampai agak } \\
\text { terjal }\end{array}$ & $\begin{array}{l}\text { Asosiasi Andic } \\
\text { Dystrudepts } \\
\text { Typic Melanudands }\end{array}$ & 0,81 & 0,08 \\
\hline 6 & $\begin{array}{l}\text { Dataran intervulkanik dan plato } \\
\text { (dataran tinggi) }\end{array}$ & $\begin{array}{ll}\text { Humic } & \text { Pachic } \\
\text { Dystrudepts } & \\
\end{array}$ & 6,06 & 0,65 \\
\hline 7 & $\begin{array}{l}\text { Colluvial kaki bukit dan kaki } \\
\text { lereng landai sampai agak landai }\end{array}$ & $\begin{array}{ll}\text { Ruptic } & \text { Alfic } \\
\text { Dystrudepts } & \\
\end{array}$ & 10,08 & 1,08 \\
\hline 8 & $\begin{array}{l}\text { Lereng bukit, curam sampai agak } \\
\text { terjal }\end{array}$ & $\begin{array}{l}\text { Asosiasi Typic } \\
\text { Dystrudepts } \\
\text { AndicDystrudepts } \\
\text { Typic Melanudands }\end{array}$ & 28,85 & 3,09 \\
\hline 9 & $\begin{array}{lll}\begin{array}{l}\text { Lembah-lembah } \\
\text { colluvial }\end{array} & \text { alluvial dan } \\
\end{array}$ & Typic Hapludands & 30,96 & 3,32 \\
\hline 10 & Lereng plato yang curam & $\begin{array}{l}\text { Asosiasi Typic } \\
\text { Melanudans } \\
\text { Andic Dystrudepts }\end{array}$ & 46,45 & 4,98 \\
\hline 11 & $\begin{array}{l}\text { Bukit tertoreh dengan punggung } \\
\text { tajam sejajar }\end{array}$ & $\begin{array}{l}\text { Asosiasi Typic } \\
\text { Hapludands } \\
\text { Andic Hapludolls }\end{array}$ & 0,56 & 0,06 \\
\hline 12 & $\begin{array}{l}\text { Plato yang terdapat bahan } \\
\text { colluvial, berlereng landai }\end{array}$ & $\begin{array}{l}\text { Asosiasi Typic } \\
\text { Hapludands } \\
\text { Humic Dystrudepts }\end{array}$ & 13,27 & 1,42 \\
\hline 13 & $\begin{array}{l}\text { Colluvial kaki bukit dan kaki } \\
\text { lereng landai sampai agak landai }\end{array}$ & $\begin{array}{l}\text { Asosiasi Typic } \\
\text { Hapludands } \\
\text { Inceptic Hapludalfs }\end{array}$ & 59,76 & 6,41 \\
\hline 14 & $\begin{array}{l}\text { Lembah-lembah alluvial dan } \\
\text { colluvial }\end{array}$ & Typic Hapludolls & 15,89 & 1,7 \\
\hline 15 & $\begin{array}{l}\text { Lereng bukit, curam sampai agak } \\
\text { terjal }\end{array}$ & Typic Hydrudands & 162,73 & 17,47 \\
\hline 16 & Lereng plato yang curam & $\begin{array}{l}\text { Asosiasi Typic } \\
\text { Melanudands } \\
\text { Andic Dystrudepts }\end{array}$ & 1,13 & 0,12 \\
\hline 17 & Lereng-lereng gunung yang curam & Typic Udipsamments & 7,71 & 0,82 \\
\hline & Jumlah & & 93.99 & 100 \\
\hline
\end{tabular}




\section{Evaluasi Lahan}

Berdasarkan sistem evaluasi lahan dan penggunaan sistem ALES (Dijkerman et al., 1997), dari evaluasi lahan yang dilakukan dengan memasukkan semua parameter yang dibutuhkan program ALES, sehingga dapat diketahui kelas kesesuaian lahan baik fisik maupun ekonomi ekonomi. Kualitas lahan yang menjadi pembatas suatu lahan ada yang bisa dilakukan usaha perbaikan dan ada juga yang tidak dapat dilakukan perbaikan. Kualitas lahan yang bisa dilakukan perbaikan adalah bahaya erosi (eh), ketersediaan hara (nf) dan retensi hara (nr). Sedangakan kualitas lahan berupa ketersediaan air (wa), tempetarur (tc) dan media perakaran (rc) tidak dapat dilakukan perbaikan karena kualitas lahan tersebut merupakan sifat alami dari lahan tersebut.

Tabel 4. Kelas kesesuaian lahan fisik

\begin{tabular}{|c|c|c|c|c|c|}
\hline SPT & Uraian SPT & Jagung & Kubis & Kentang & Wortel \\
\hline 1 & Andic Dystrudepts & $\mathrm{S} 2 \mathrm{nr} / \mathrm{rc} / \mathrm{wa}$ & S3rc & S2nf & S3nf \\
\hline \multirow[t]{2}{*}{2} & \multirow{2}{*}{$\begin{array}{l}\text { Asosiasi Andic Dystrudepts } \\
\text { Lithic Udipsamments }\end{array}$} & S3oa & $\mathrm{S} 3 \mathrm{eh} / \mathrm{nr}$ & S3oa & S3nf \\
\hline & & Noa & Noa & Noa & S3nf \\
\hline \multirow{2}{*}{3} & \multirow{2}{*}{$\begin{array}{l}\text { Asosiasi Andic Dystrudepts } \\
\text { Typic Hapludands }\end{array}$} & $\mathrm{S} 2 \mathrm{nr} / \mathrm{rc} / \mathrm{wa}$ & S3rc & S2nf & S3nf \\
\hline & & $\begin{array}{l}\mathrm{S} 2 \mathrm{eh} / \mathrm{nf} / \mathrm{nr} / \\
\mathrm{rc}\end{array}$ & $\mathrm{S} 3 \mathrm{eh} / \mathrm{nr}$ & $\mathrm{S} 2 \mathrm{eh} / \mathrm{nr}$ & Neh \\
\hline 4 & Typic Melanudands & $\mathrm{S} 2 \mathrm{nr} / \mathrm{rc} / \mathrm{wa}$ & S3nf & S2nf & S3nf \\
\hline \multirow[t]{2}{*}{5} & \multirow{2}{*}{$\begin{array}{l}\text { Asosiasi Andic Dystrudepts, } \\
\text { Typic Melanudands }\end{array}$} & $\mathrm{S} 2 \mathrm{nr} / \mathrm{rc} / \mathrm{wa}$ & S3nf & S2nf & S3nf \\
\hline & & $\mathrm{S} 2 \mathrm{nr} / \mathrm{rc} / \mathrm{wa}$ & S3nf & S3nr & S3nf \\
\hline 6 & Humic Pachic Dystrudepts & S3oa & S3nf & S3oa & S3nf \\
\hline 7 & Ruptic Alfic Dystrudepts & $\mathrm{S} 2 \mathrm{nr} / \mathrm{rc} / \mathrm{wa}$ & S3nf & S3nr & S3nf \\
\hline \multirow{2}{*}{8} & \multirow{2}{*}{$\begin{array}{l}\text { Asosiasi Andic Dystrudepts } \\
\text { Typic Melanudands }\end{array}$} & $2 \mathrm{nr} / \mathrm{rc} / \mathrm{wa}$ & S3nf & S2nf & S3nf \\
\hline & & S3oa & S3nf & S3oa & S3nf \\
\hline 9 & Typic Hapludands & $\mathrm{S} 2 \mathrm{nr} / \mathrm{rc} / \mathrm{wa}$ & S3nf & S2nf & S3nf \\
\hline \multirow[b]{2}{*}{10} & \multirow{2}{*}{$\begin{array}{l}\text { Asosiasi Typic Melanudands } \\
\text { Typic Hapludands }\end{array}$} & S3oa & $\mathrm{S} 3 \mathrm{eh} / \mathrm{nr}$ & S3oa & S3nf \\
\hline & & S3oa & $\mathrm{S} 3 \mathrm{eh} / \mathrm{nr}$ & S3oa & S3nf \\
\hline \multirow[t]{2}{*}{11} & \multirow{2}{*}{$\begin{array}{l}\text { Asosiasi Typic Hapludands } \\
\text { Andic Hapludolls }\end{array}$} & $\mathrm{S} 2 \mathrm{nr} / \mathrm{rc} / \mathrm{wa}$ & S3nf & S3nr & S3nf \\
\hline & & $\mathrm{S} 3 \mathrm{O}$ & $\mathrm{S} 3 \mathrm{eh} / \mathrm{nr}$ & S3oa & S3nf \\
\hline \multirow[t]{2}{*}{12} & \multirow{2}{*}{$\begin{array}{l}\text { Asosiasi Typic Hapludands } \\
\text { Humic Dystrudepts }\end{array}$} & S3oa & S3eh & S3oa & S3nf \\
\hline & & S3oa & S3eh & S3oa & S3nf \\
\hline \multirow[t]{2}{*}{13} & \multirow{2}{*}{$\begin{array}{l}\text { Asosiasi Typic Hapludands } \\
\text { Inceptic Hapludalfs }\end{array}$} & $\mathrm{S} 2 \mathrm{nr} / \mathrm{rc} / \mathrm{wa}$ & S3rc & S2nf & S3nf \\
\hline & & $\mathrm{S} 2 \mathrm{nr} / \mathrm{rc} / \mathrm{wa}$ & S3rc & S2nf & S3nf \\
\hline 14 & Typic Hapludolls & $\begin{array}{c}\mathrm{S} 2 \mathrm{eh} / \mathrm{nf} / \mathrm{nr} / \\
\mathrm{rc}\end{array}$ & $\mathrm{S} 3 \mathrm{eh} / \mathrm{nr}$ & S2nf & Neh \\
\hline 15 & Typic Hydrudands & $\begin{array}{c}\mathrm{S} 2 \mathrm{eh} / \mathrm{nf} / \mathrm{nr} / \\
\mathrm{rc}\end{array}$ & $\mathrm{S} 3 \mathrm{eh} / \mathrm{nr}$ & S2nf & Neh \\
\hline \multirow[t]{2}{*}{16} & \multirow{2}{*}{$\begin{array}{l}\text { Asosiasi Typic Melanudands } \\
\text { Andic Dystrudepts }\end{array}$} & S3oa & S3nf & S3oa & S3nf \\
\hline & & $\mathrm{S} 2 \mathrm{nr} / \mathrm{rc} / \mathrm{wa}$ & S3nf & S2nf & S3nf \\
\hline 17 & Typic Udipsamments & Noa & Noa & Noa & Neh \\
\hline
\end{tabular}


B. Siswanto dan W. Fikrinda/ Buana Sains Vol 17 No 2 : 125-136

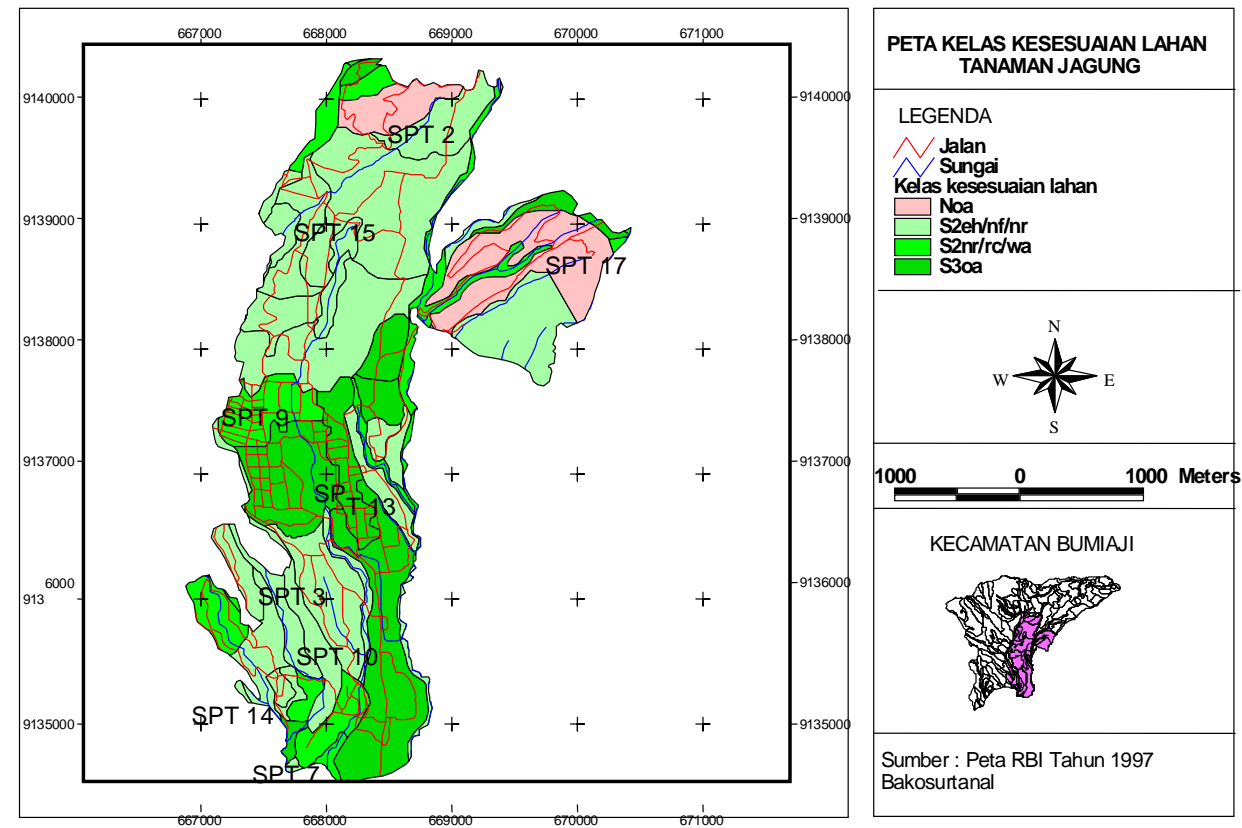

Gambar 5. Peta Kelas Kesesuaian Lahan Tanaman Jagung (aktual)

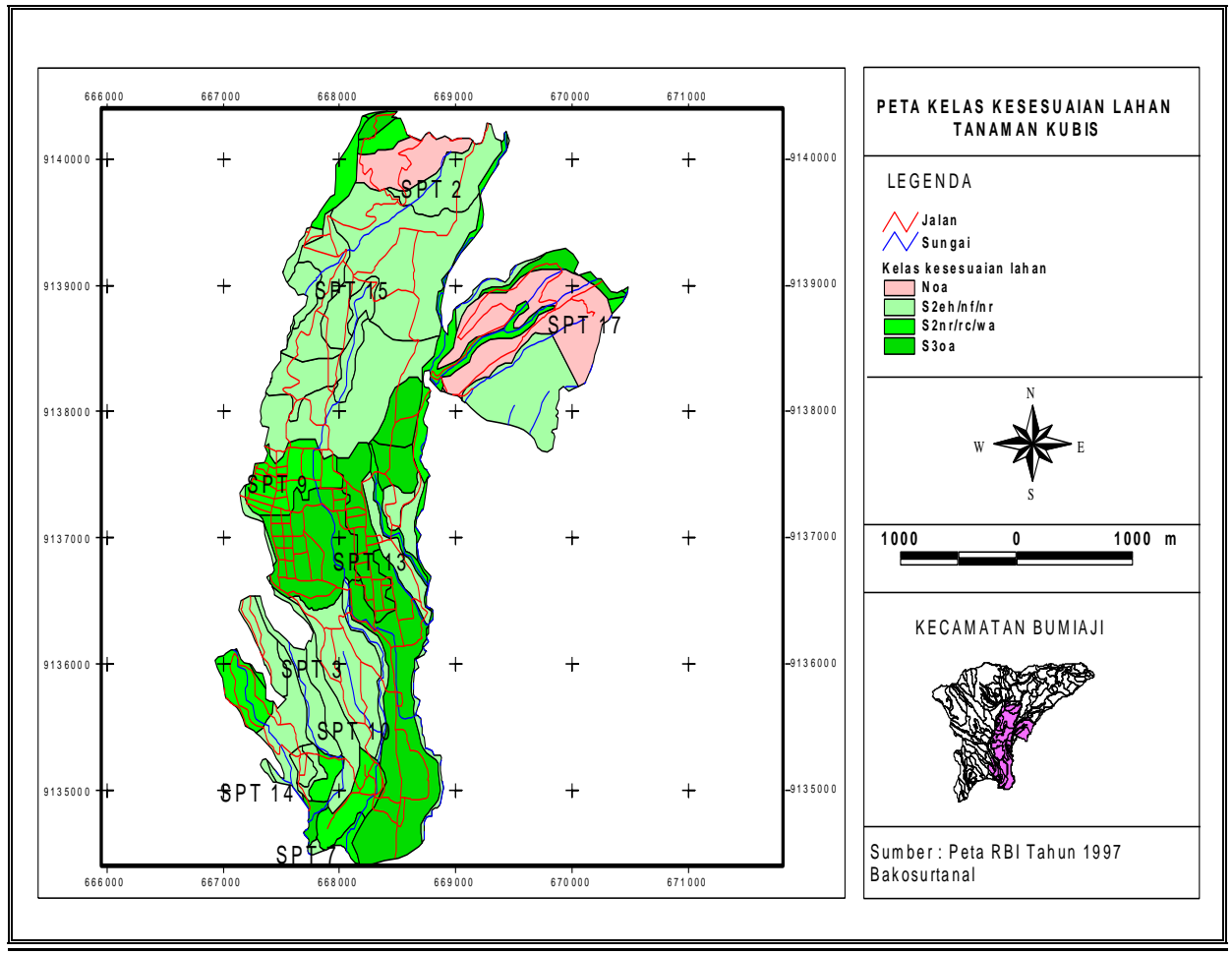

Gambar 6. Peta Kelas Kesesuaian Lahan Tanaman Kubis (aktual) 
B. Siswanto dan W. Fikrinda/ Buana Sains Vol 17 No 2 : 125-136

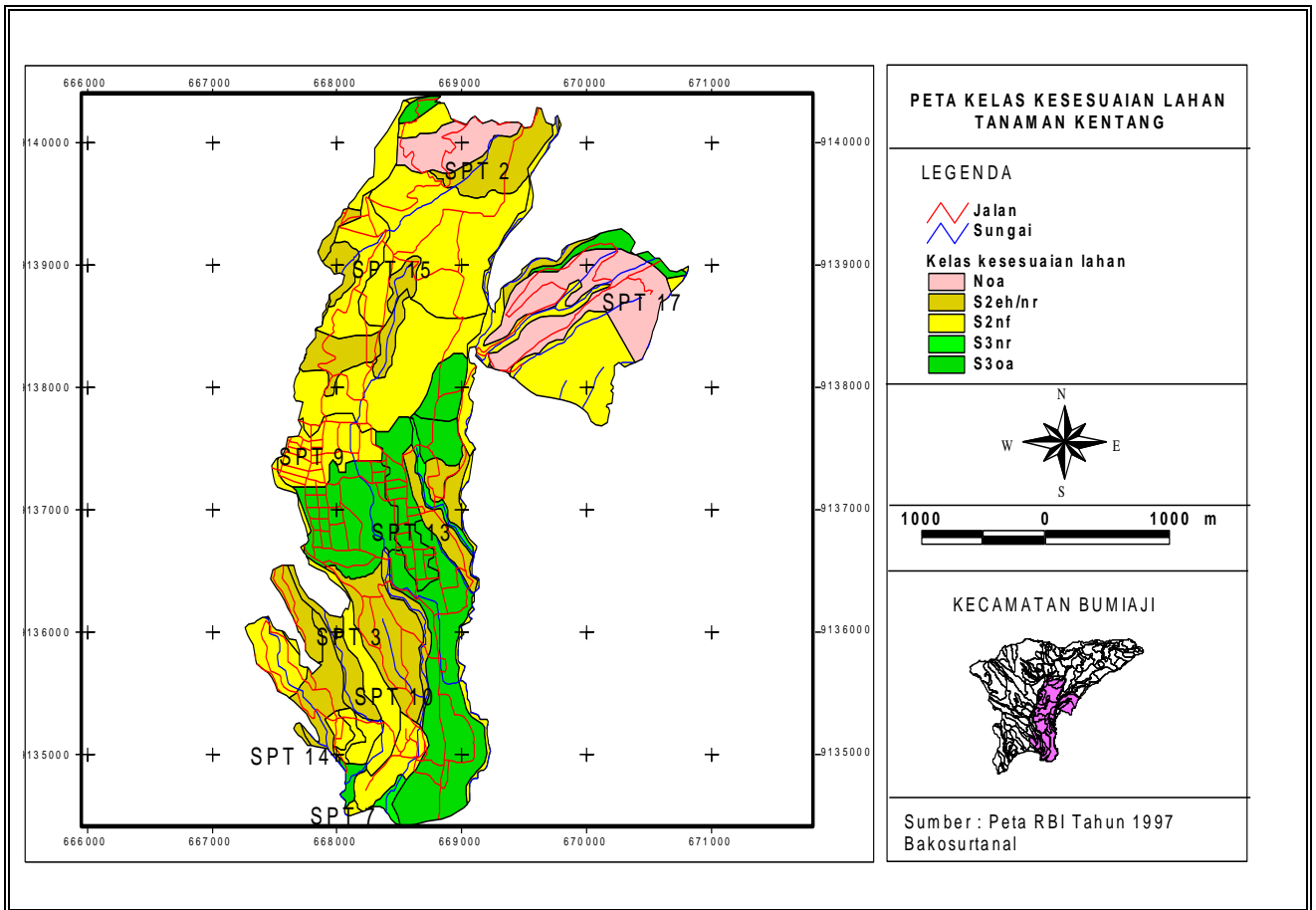

Gambar 7. Peta Kelas Kesesuaian Lahan Tanaman Kentang (aktual)

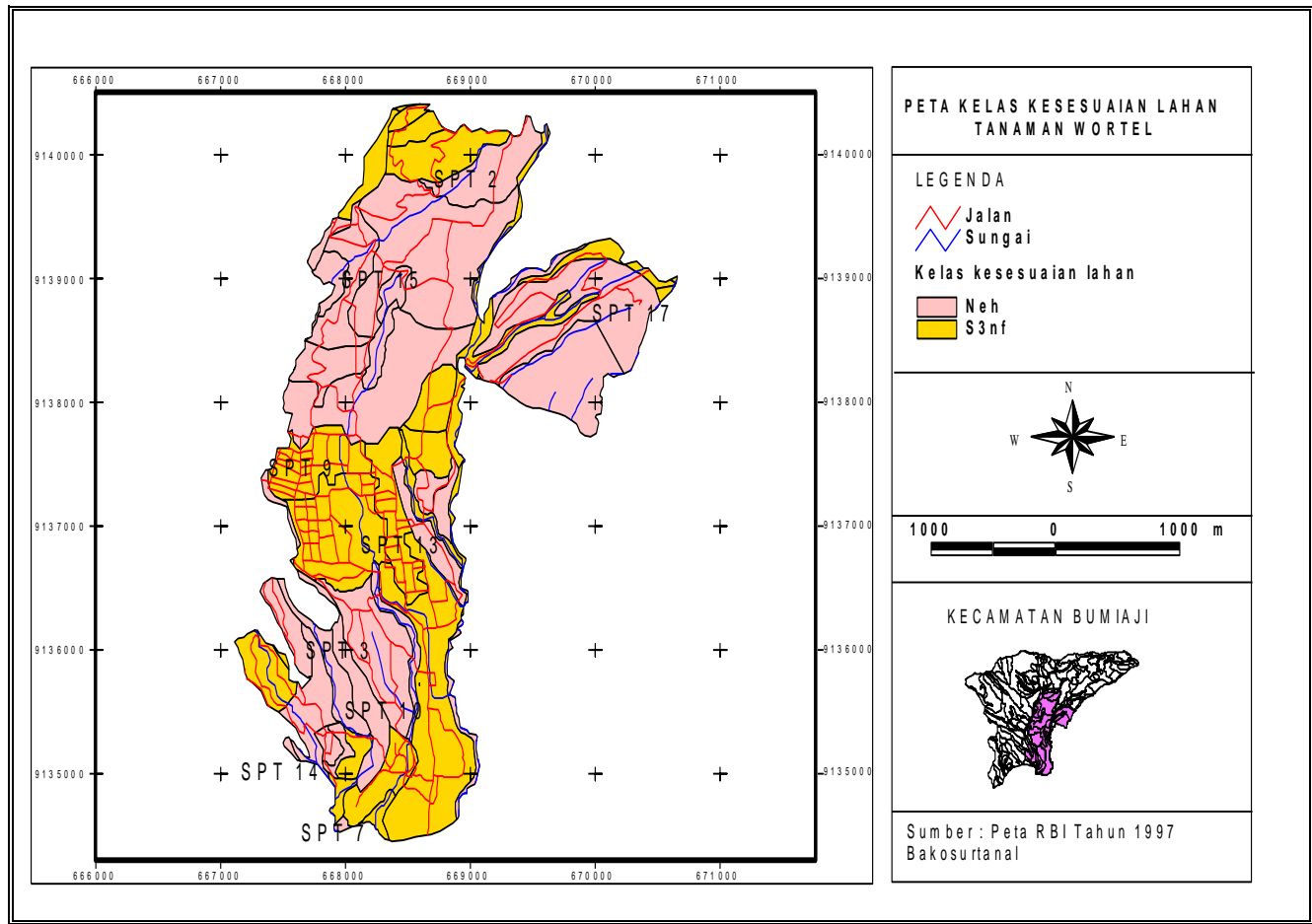

Gambar 8. Peta Kelas Kesesuaian Lahan Tanaman Wortel (aktual)

Kelas kesesuaian lahan secara ekonomi masih sangat berhubungan dengan kelas kesesuaian lahan secara fisik. Apabila suatu lahan memiliki kelas 
kesesuaian lahan fisik yang baik maka kelas kesesuaian lahan ekonominnya juga baik.

Parameter yang digunakan dalam evaluasi lahan secara ekonomi adalah NPV, IRR, BCR dan GM . Nilai-nilai tersebut pada tanaman yang dievaluasi memiliki nilai yang positif, maka dapat disimpulkan bahwa usaha tani yang dilakukan di daerah penelitian termasuk menguntungkan.

Tabel 5. Kelas kesesuaian lahan ekonomi dan keuntungan

\begin{tabular}{|l|l|l|l|l|}
\hline SPT & Tanaman & Kelas & $\begin{array}{l}\text { Keuntungan } \\
(\mathrm{Rp})\end{array}$ & $\begin{array}{l}\text { Persen } \\
(\%)\end{array}$ \\
\hline $6,8,9,10,3,4$ & Jagung & S3 & 7.329 .999 & 40 \\
\hline $1,5,7,8,11,12,16$ & & $\mathrm{~N} 1$ & 3.580 .000 & 20 \\
\hline 2,17 & & $\mathrm{~N} 2$ & 0 & 0 \\
\hline $1,3,4,5,6,7,8,9,10,11,12,13,14,15,16$ & Kubis & $\mathrm{N} 1$ & 11.840 .600 & 20 \\
\hline 2,17 & & $\mathrm{~N} 2$ & 0 & 0 \\
\hline $1,3,4,5,9,13,14,15$ & Kentang & S3 & 39.748 .666 .65 & 40 \\
\hline $6,7,8,10,11,12,16$ & & $\mathrm{~N} 1$ & 23.932 .000 & 20 \\
\hline 2,17 & & $\mathrm{~N} 2$ & 0 & 0 \\
\hline $1,3,4,5,6,7,8,9,10,11,12,13,16$ & Wortel & $\mathrm{N} 1$ & 6.105 .000 & 20 \\
\hline $2,14,15,17$ & & $\mathrm{~N} 2$ & 0 & 0 \\
\hline
\end{tabular}

\section{Kesimpulan}

1. Penggunaan program ALES dapat digunakan untuk mengevaluasi kesesuaian lahan tanaman semusim yaitu, jagung, kubis, kentang dan wortel di desa Tulungrejo.

2. Hasil evaluasi lahan untuk tanaman jagung, kubis dan kentang memiliki kelas tidak sesuai (N1) pada SPT 2 dan SPT 17 sedangkan tanaman wortel memiliki kelas tidak sesuai $(\mathrm{N})$ pada SPT 3, SPT 14 dan SPT 15

3. Secara ekonomi usaha budidaya tanaman jagung, kubis, kentang dan wortel termasuk menguntungkan, karena tidak memiliki parameter ekonomi yang bernilai negatif.

\section{Daftar Pustaka}

Djaenudin, D, A. Mulyani, H. Subagyo. M. Hendrisman dan N Suharta, 2003. Kriteria Kesesuaian Lahan Untuk Komoditas Pertanian. Pusat
Penelitian Tanah dan Agroklimat. Departemen Pertanian. Bogor

Djikerman, J.C. dan J Widyanigsih. 1986. Evaluasi Lahan. Jurusan Tanah. Fakultas Pertanian Universitas. Brawijaya

FAO, 1976. A Framework For Land Evaluation, Soil Bulletin 32, FAO Rome

Foth, 1978. Dasar- Dasar Ilmu Tanah. Edisi keenam. Erlangga. Jakarta

Hardjowigeno. S dan Widiatmaka, 2001. Kesesuaian Lahan dan perencanaan Tataguna Tanah.Jurusan Tanah Fakultas Pertanian. IPB. Bogor.

Marsoedi, 1997. Pedoman Klasifikasi Landform. Centre For Soil And Agroclimate Research. ARCADIS. PT Andal Agrikarya Prima. Bogor

Munir, 1996. Tanah-Tanah Utama Indonesia. Karakteristik, Klasifikasi dan Pemanfatanya. Pustaka Jaya. Jakarta 
Rayes, 1995. Survei Tanah dan Evaluasi Lahan. Jurusan Tanah, Fakultas Pertanian . Unibraw

Rossiter D dan V. Wambeke. 1997. Autometed Land Evaluation System (ALES). Departement of agronomi Coriell University. Ithaca. New York. USA

Rossiter, D.G. 2003. Biophysical Models In Land Evaluation. Encyclopedia Of Life Support System (EOLSS) 1 secsion 1,5 "Land Use and Land Covers". EOLSS Publishers.

Situmorang. RL, 1992. Geologi Lembar Waru - Sumenep, Jawa. Departemen Pertimbangan dan Energi Direktorat
Jendral Geologi dan Sumber Daya Mineral. Pusat penelitian dan Pengembangan Geologi. Bandung. Indonesia.

Soil Survei Staff 1998. Soil Taxonomy Soil Resources. Development and Conservation Services Land and Water Development Division. Puslitbangtanak. Departemen Pertanian. Bogor.

Soekartawi, 1995. Analisis Usaha Tani. Penerbit Universitas Indonesia.(UI Press). Jakarta 